\title{
MICROMORPHOLOGY OF NECTARIES OF RHODODENDRON CATAWBIENSE MICHX. AT DIFFERENT FLOWER DEVELOPMENT STAGES
}

\author{
Elżbieta Weryszko-Chmielewska, Mirosława Chwil, Magdalena Michońska
}

\author{
Department of Botany, Agricultural University, Akademicka 15, 20-950 Lublin, Poland \\ e-mail: elzbieta.weryszko@ar.lublin.pl
}

Received: 16.11 .2007

\begin{abstract}
S u m m a r y
The analysis of the structure of floral nectaries of Rhododendron catawbiense Michx. was performed using stereoscopic, light and scanning electron microscopy. Nectaries were sampled at different development stages: closed bud, budburst and full bloom. The nectary gland exhibits clear ribbings corresponding to five small ribs of the ovary. In the top part of the gland, unicellular and multicellular non-glandular trichomes occur in great density. The upper surface of the nectary differs from its lateral surface by a stronger degree of cuticle development. Stomata are evenly distributed on the upper surface and in the higher regions of the lateral wall. The cuticle forms clear striae on the surface of stomatal cells. Stomata at different development stages were observed, as well as the beginning of nectar secretion which takes places already in the closed bud.
\end{abstract}

Key words: nectary, micromorphology, epidermis, stomata, cuticle, Rhododendron catawbiense

\section{INTRODUCTION}

Rhododendron catawbiense Michx. comes from the mountains of North America (S e n e t a and D olat owski, 2007). It was brought to Europe in the 19 th century. This species is classified as ornamental, medicinal and melliferous plants (K o ndrat ow i c z and $\mathrm{Czekals} \mathrm{k} \mathrm{i,} \mathrm{1984;} \mathrm{B} \mathrm{a} \mathrm{u} \mathrm{e} \mathrm{r,} \mathrm{1986).} \mathrm{It} \mathrm{is} \mathrm{charac-}$ terised by good acclimatization and high frost resistance (Czekals ki, 1980; S e neta and Dolatow ski, 2007). It is a parent used to obtain ornamental hybrids and rhododendron varieties ( $\mathrm{C} \mathrm{z}$ e k a l s k i , 1980; $\mathrm{M} \mathrm{u}-$ ras, 1994; S e net a and D ol at ow s ki, 2007). It produces large, bell-shaped, lilac-pink flowers. In Polish conditions it blooms in May and June. Flowers of various Rhododendron species offer pollen and nectar to pollinators (Maurizio and Graf1, 1969; Bauer, 1986; Weryszko-Chmielewska and Chwil, 2005).
Floral nectaries in Rhododendron surround the basal part of the ovary. Non-glandular and glandular hairs growing on the ovary form their protective cover from the top (We ry s z k - Chmie lew ska et al. 2003; Weryszko-Chmielewska and Chwil, 2005, 2007).

The structure of nectaries of a dozen or so species from the genus Rhododendron was investigated by Philipson (1985) and he proved that a particular category of the nectary structure corresponds to respective subdivisions. The characteristics of the nectary structure in Rhododendron luteum was described in the papers of Weryszk o-Chmi e lew s a et al. (2003) and in Weryszko-Chmielew ska and Chwil (2005), whereas the micromorphology of the nectary of $R h$. japonicum was presented in the paper of Werys zkoChmielewska and Chwil (2007).

This paper study is a continuation of comparative studies of floral nectaries of different species from the genus Rhododendron. In the study, the micromorphology of the floral nectary of Rhododendron catawbiense was determined using scanning electron microscopy. Changes in the structure of the nectary epidermis were also investigated at three flower development stages.

\section{MATERIALS AND METHODS}

The studies conducted in the years 2006-2007 covered floral nectaries of Rhododendron catawbiense Michx. Shrubs of this taxon grew in the Botanical Garden of the Maria Curie-Skłodowska University in Lublin, Poland. Flowers with the nectaries were sampled for microscopic observations at the closed bud, budburst and open flower stage (the fifth day of the flower life). Morphometric examination was performed under a stereoscopic microscope.

The micromorphology of the structure of the secretory epidermis was analysed using scanning electron 
microscopy (SEM). Flower fragments with the ovary were fixed in $4 \%$ glutaraldehyde and $0.1 \mathrm{M}$ phosphate buffer with a $\mathrm{pH}$ of 7.0 at room temperature for 4 hours. After being dehydrated in acetone, the plant material was dried at critical point in liquid $\mathrm{CO}_{2}$ and coated with gold using the CS 100 Sputter Coater. Observations of the nectaries were made using the BS - 340 Tesla electron microscope.

\section{RESULTS}

The location of the nectary surrounding with a wide layer the base of the ovary superior the flower of Rhododendron catawbiense can be already noticed at a small magnification (Fig. 1a). Average dimensions of the ovary in this species are $4.6 \mathrm{~mm}$ in height and 2.5 $\mathrm{mm}$ in width. The nectary reaches the height of $1.3 \mathrm{~mm}$, which is about $1 / 3$ of the ovary height, and its thickness measured along the radius is $0.8 \mathrm{~mm}$. In the longitudinal section of the flower, the nectary forms a quite large, rounded convexity protruding in its upper part from the ovary (Fig. 1c). Numerous vascular bundles run in the nectar-secreting tissue. In the cross section of the nectary, 5 poorly noticeable ribs can be observed. However, the nectary gland exhibits clearer ribbing corresponding to particular ribs of the ovary (Figs 1a, d).

The top part of the nectary is densely covered with non-glandular trichomes (Figs la, d, e), which are absent on the gland surface adjacent to the ovary (Fig. 1e). These trichomes are different sized and shaped. Among them, there are unicellular and multicellular trichomes, sharpended or rounded at the top (Figs 2 a-e). Some of them grow beside each other in groups (Fig. 1a). The surface of the trichomes is covered by the cuticle with clear, different ornamentation. Light microscopy observations show that the trichomes are live and marked by a quite thin cell wall and the presence of chloroplasts (Figs 2f-i). Unlike the nectary, sparsely distributed non-glandular and secretory trichomes occur on the ovary surface (Figs $1 \mathrm{a}, \mathrm{b}$ ).

The secretory epidermis of the nectary is composed of polygonal cells with convex or slightly wavy outer walls (Figs 1f, g). The cuticular ornamentation shows great differentiation. In the closed bud, the horizontally situated upper surface of the nectary is characterised by the presence of clearly developed, wavy cuticular striae (Fig. 3a). In the fully-developed flower, the micromorphology of the walls of these cells is very similar (Fig. 3e). The lateral walls of the nectary are covered by differently-structured epidermis in which groups of cells lying next to each other have a smooth cuticle (Figs 3c, d) or clear parallel running striae (Fig. 4e). Such a differentiation of cuticular sculpture of the lateral region of the nectary also remains after flower opening. The epidermal cells located on the surface of the ribs are generally characterised by more strongly developed cuticular striae than the cells situated in the hollows between the ribs. Better developed striae are also observed on the walls of cells from the higher regions of the nectary.

Anomocytic stomata are distributed quite evenly on the nectary surface and they are located at the level of other epidermal cells (Figs 1f, g). An exception is the basal part of this gland where there are many fewer stomata. In the closed and bursting bud, not fully developed stomata were frequently observed, with the pore completely or partially covered by the cuticle layer (Fig. 3a). These stomata were different sized and had relatively poorly developed outer cuticular ledges (Figs $3 \mathrm{a}-\mathrm{c})$. At full bloom stage, most stomata were marked by a stronger development of outer cuticular ledges and a large aperture of the pore (Figs 3d, e). Circularly running cuticular striae were observed on the surface of many stomatal cells (Figs 3 a-e).

The microscopic observations show that nectar secretion in Rhododendron catawbiense starts in the closed, fully coloured bud. This fact is confirmed by images from the scanning microscope, indicating stomatal nectar secretion. In the case of numerous stomata, the beginning of secretion could be observed, associated with the release of nectar forming different-sized droplets at the outer aperture of the stoma (Figs 4a-g). Similar observations were noted at the opening bud stage. But at full bloom stage, no presence of nectar droplets by the nectary stomata was found. At this stage, most stomata were characterised by an open outer and central aperture (Fig. 3e). In addition to well-developed stomata, not numerous, non-functioning stomata were observed which had reduced dimensions.

\section{DISCUSSION}

The size of the nectary gland in flowers of Rhododendron catawbiense much exceeds the dimensions of nectaries occurring in flowers of $R h$. luteum and $R h$. japonicum studied by us previously (Tab. 1).

The height of the nectary of $R h$. catawbiense was on the average $28 \%$ of the ovary height, whereas in $R h$. luteum the nectary gland reached the height amounting to $20 \%$ of the ovary height (We r y s z k o-C h m i elew s a and Chwil, 2005), and in Rh. japonicum $11 \%$ of the ovary height (We ry s z k o - C h m i e l e w $\mathrm{s} \mathrm{k}$ a and $\mathrm{Chw}$ i 1, 2007). Also the width of nectariferous tissue of $R h$. catawbiense, measured along the radius, was much larger than in the two mentioned species, what is a result of a more convex shape of this gland.

Based on studies of over a dozen species from the genus Rhododendron, which did not relate to Rh. catawbiense, Philips on (1985) distinguished three main types found within this genus. It seems that the nectary of $R h$. catawbiense can be classified as type A which is marked by the formation of large, rounded bulges at the 
Table 1

Comparison of the ovary and nectary size of three Rhododendron species.

\begin{tabular}{|c|c|c|c|c|}
\hline \multirow[t]{2}{*}{ Species } & \multirow{2}{*}{$\begin{array}{l}\text { Ovary } \\
\text { height } \\
(\mathrm{mm})\end{array}$} & \multicolumn{2}{|c|}{ Nectary } & \multirow[t]{2}{*}{ Author } \\
\hline & & Height (mm) & $\%$ of ovary height & \\
\hline Rh. luteum & 5.0 & 1.0 & 20 & $\begin{array}{l}\text { Weryszko-Chmielewska } \\
\text { and Chwil (2005) }\end{array}$ \\
\hline Rh. japonicum & 5.5 & $0.6-0.7$ & 11 & $\begin{array}{l}\text { Weryszko-Chmielewska } \\
\text { and Chwil (2007) }\end{array}$ \\
\hline Rh. catawbiense & 4.6 & 1.3 & 28 & Results in the present pape \\
\hline
\end{tabular}
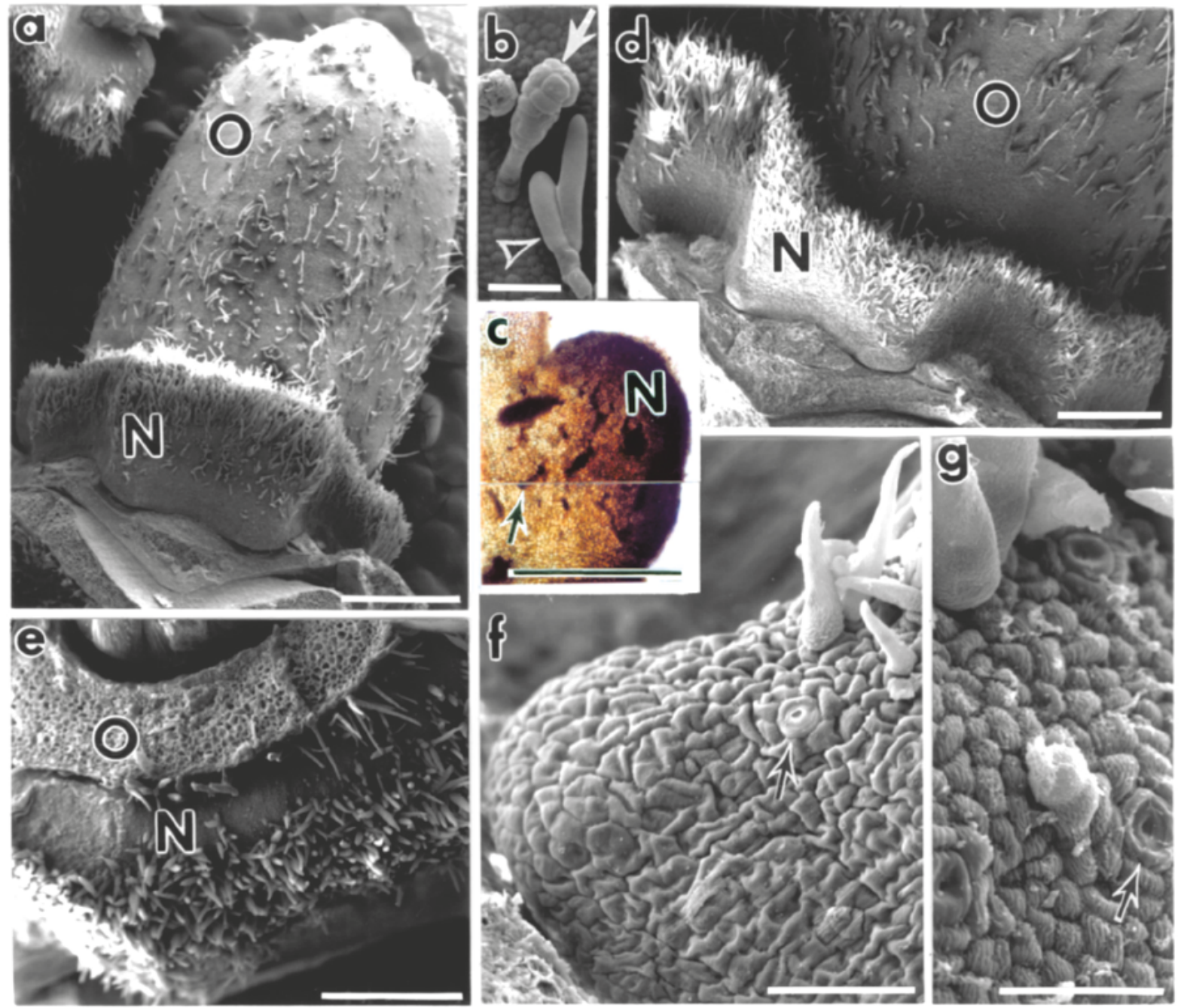

Fig. 1. Fragments of the ovary and nectary in flowers of Rhododendron catawbiense (SEM, LM). a, d - visible is the nectary $(\mathrm{N})$ forming a ribbed structure corresponding to the convexities of the ovary $(\mathrm{O})$ : visible non-glandular trichomes occur in the top part of the nectary; b - multicellular secretory (arrow) and non-glandular trichomes (arrowhead) from the nectary surface; $\mathrm{c}$ - longitudinal section of the nectary $(\mathrm{N})$ seen under a light microscope: visible numerous vascular bundles (arrow); e - cross section of the ovary (O) and the nectary upper surface $(\mathrm{N})$; f, g - lateral part of the nectary: visible trichomes and stomata (arrows). a, d - bar $=1 \mathrm{~mm} ; \mathrm{b}-\mathrm{bars}=200 \mu \mathrm{m}$; c, e - bars $=500 \mu \mathrm{m} ; \mathrm{f}-$ bar $=100 \mu \mathrm{m} ; \mathrm{g}-$ bar $=40 \mu \mathrm{m}$. 

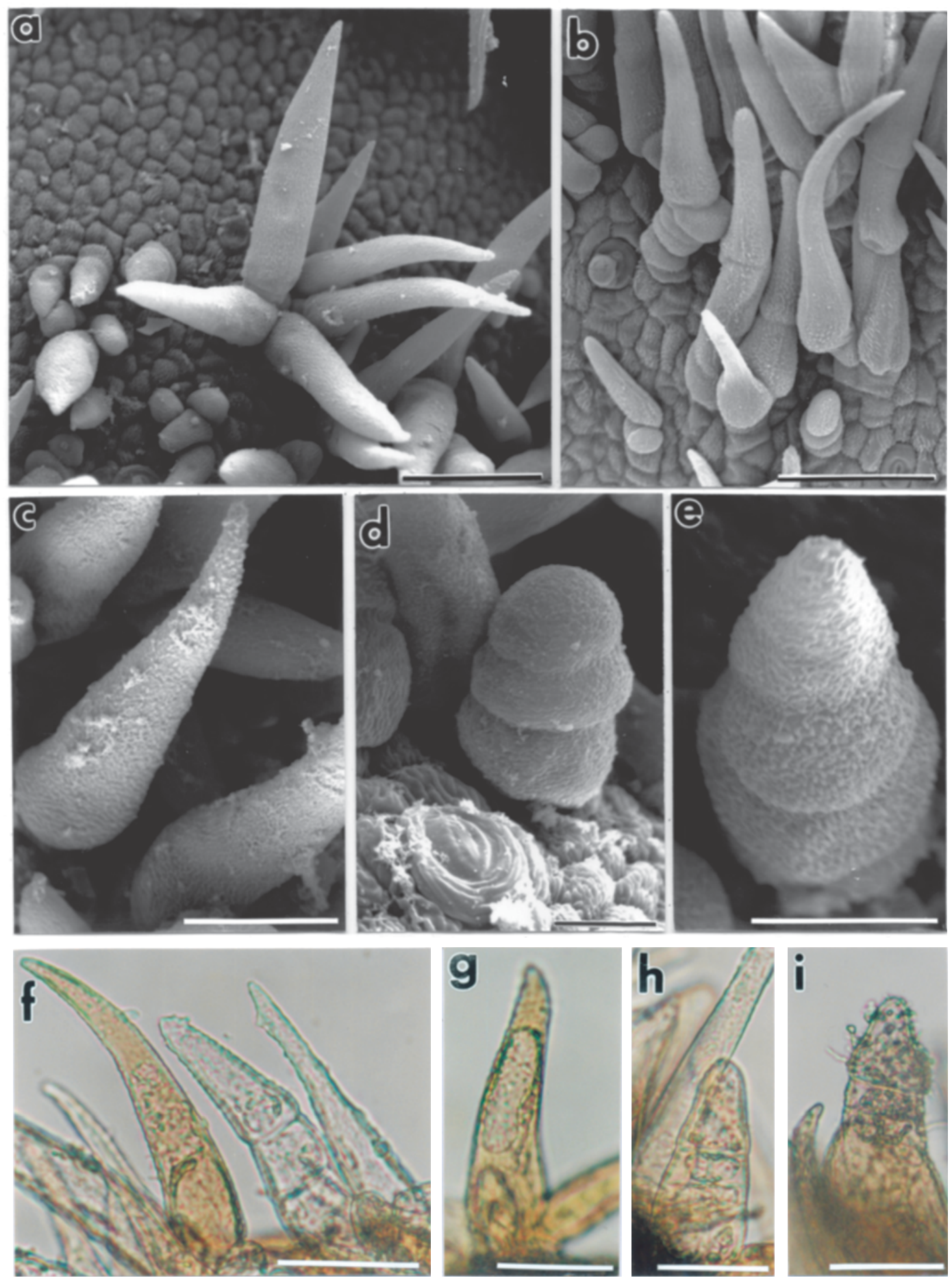

Fig. 2. a-e - Fragments of the top part of the nectary with unicellular and multicellular protective hairs (SEM). f-i - non-glandular trichomes $(\mathrm{LM})$ chloroplasts visible in the cell cytoplasm. $\mathrm{a}-\mathrm{bar}=60 \mu \mathrm{m} ; \mathrm{b}-\mathrm{bar}=70 \mu \mathrm{m} ; \mathrm{c}, \mathrm{f}-\mathrm{bar}=30 \mu \mathrm{m} ; \mathrm{d}, \mathrm{e}, \mathrm{g}$, h, $\mathrm{i}-$ bars $=20 \mu \mathrm{m}$. 

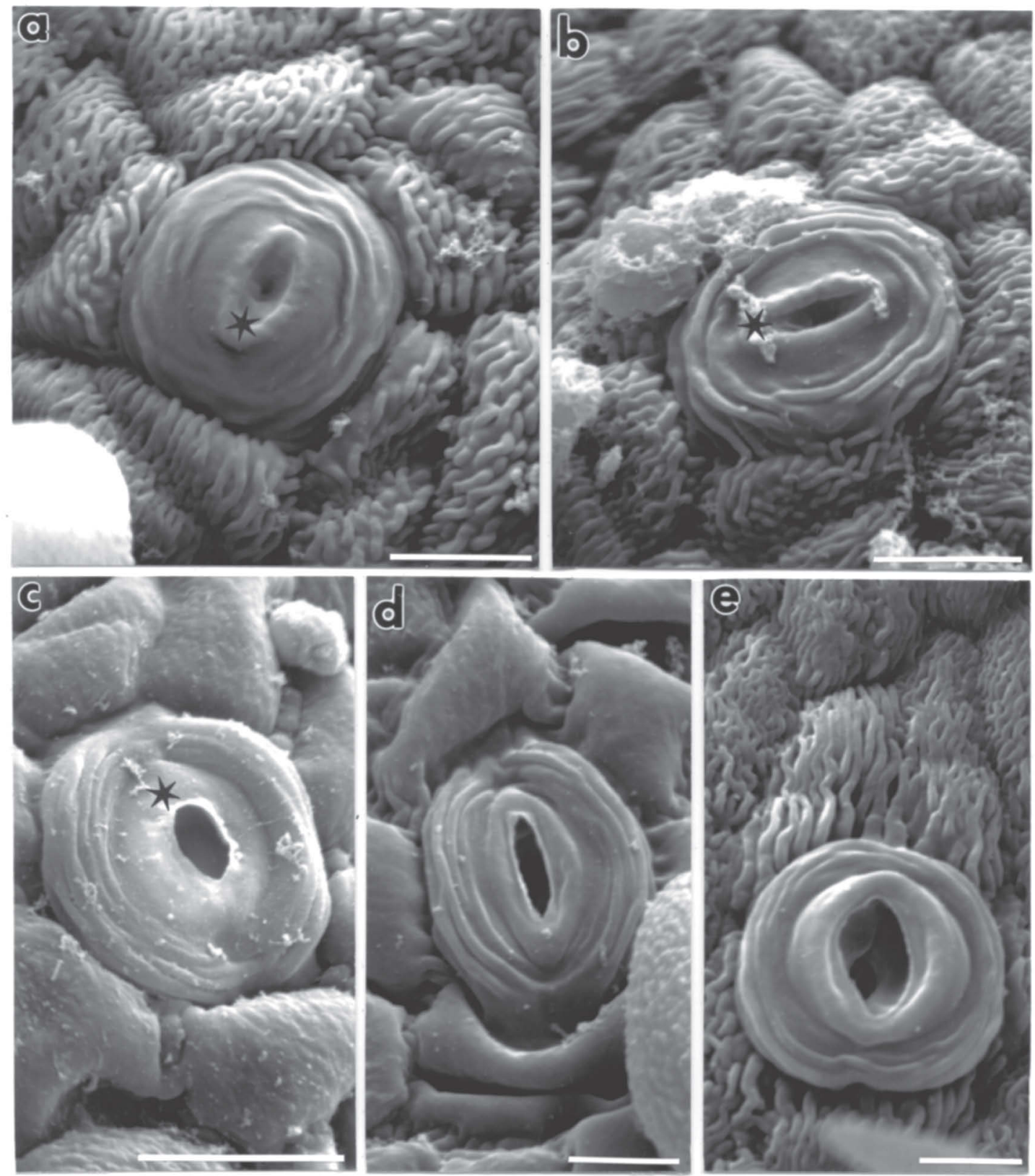

Fig. 3. Fragments of the surface of secretory epidermis of nectaries from different flower development stages: $a, b$ - closed bud; $\mathrm{c}$ - open bud; d, e - open flower. Visible cuticular striae on the surface of epidermal cells and stomata with the cuticle covering their outer apertures to a different degree (asterisk) and circularly running cuticular striae on the surface of stomata. a, b, d, $\mathrm{e}-$ bars $=10 \mu \mathrm{m} ; \mathrm{c}-$ bar $=20 \mu \mathrm{m}$. 

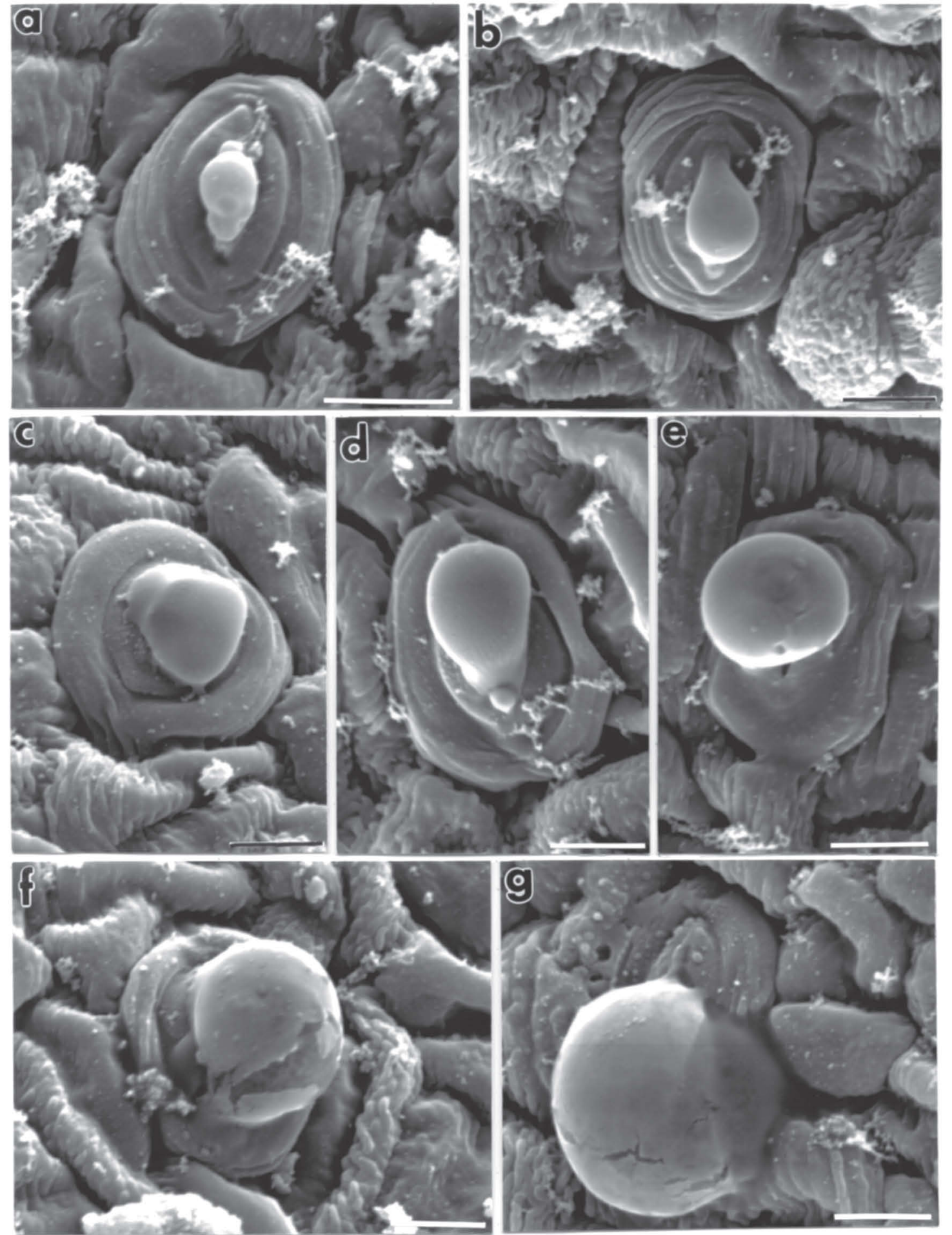

Fig. 4. a-g. Fragments of the secretory epidermis of nectaries from closed bud - beginning of nectar secretion; visible different-sized nectar droplets flowing out of stomata. $\mathrm{a}-\mathrm{g}-\mathrm{bars}=10 \mu \mathrm{m}$. 
base of the ovary. The abovementioned author observed such nectary type in $R h$. jasminiflorum.

The top part of the nectary of $R h$. catawbiense was marked by the presence of densely growing non-glandular trichomes of different structure. The presence of trichomes on the whole surface of the nectary was recorded by $\mathrm{Philips}$ on (1985) in Rh. konori. But in most Rhododendron species studied by Philipson (1985), the nectary surface was covered in its upper part with unicellular trichomes which occupied an area from one third to half of the nectary height. However, we did not find the presence of trichomes on the nectaries of the species previously studied by us (Rh. luteum and $R h$. japonicum).

Both in Rh. catawbiense and in other studied species of Rhododendron (P h i 1 i p s o n, 1985; W e r y s z k o-Ch mi e lew s k a and Chwi 1, 2005; 2007) nectar secretion took place through the stomata. A recurring feature in the species from this genus studied by us is the asynchronous development of stomata on the nectary surface which manifested itself in the presence of a certain number of not fully developed stomata, even at the end of flowering. At the end of the flowering stage, most stomata had open outer and central apertures. In some other plant species, an uneven rate of stomata maturation was also observed in nectaries (D a v i s, 1997; 2006; G a ffal et al. 1998).

We observed the beginning of nectar secretion in closed buds only in Rh. catawbiense, which was associated with the appearance of different-sized nectar droplets at the aperture of the stoma.

Another characteristic of the nectaries of Rhododendron is the occurrence of cuticle with different micromorphology, depending on the place on the nectary surface. The upper surface areas and those located on the convex parts of the nectary were marked by a well-developed, strongly folded cuticle with striated ornamentation, whereas areas of smooth cuticle were observed in the hollows between the ribs and in the lower part of the nectary in Rh. catawbiense and Rh. japonicum. It follows from that that a well-developed cuticle layer accompanied the upper parts of the nectary exposed to the effect of solar radiation, what is probably connected with its protective function. It is known from studies of other authors that the rich cuticular sculpture causes a stronger dispersion of sun rays and protects against the harmful effect of ultraviolet rays (M i r o s l a v o v, 1974; J u n i per and J e ffree, 1983).

\section{CONCLUSIONS}

1. The nectary gland of Rhododendron catawbiense forms a separate structure surrounding the base of the ovary in the form of a wide, ribbed belt.

2. At three flower development stages, the differentiation of cuticle ornamentation is visible in different parts of the nectary, with the strongest sculpture occurring in the top part of the nectary.

3. The beginning of nectar secretion took place already in the closed bud where different-sized nectar droplets were observed at the outer aperture of the pore.

\section{REFERENCES}

Bauer P. J. 1986. Bumblebee pollination on a southern Appalachian grass bald and narcotic Bumblebee pollination on a southern Appalachian grass bald and narcotic nectar in Angelica triquinata Apiaceae. PhD Thesis, University of North Carolina, USA.

Czekalski M. 1980. Aklimatyzacja różaneczników - Rhododendron 'Catawbiense - Hybridum' i Rh. 'Cunninghams White' w Polsce. / Acclimatization of rhododendrons 'Catawbiense and Hybridum' i Rh. 'Cunninghams White' - in Poland. Rocz. AR Pozn. Rozpr. Nauk. 102.

Davis M. 2006. Floral nectar production and nectary anatomy and ultrastructure of Echinacea purpurea (Asteraceae). Ann. Bot. 97(2): 177-193.

Davis A. R. 1997. Influence of floral visitation on nectary - sugar composition and nectary surface changes in $E u$ calyptus. Apidologie, 28: 27-42.

Gaffal K. P., Heimler W., El-Gammal S. 1998. The floral nectary of Digitalis purpurea L. Structure and nectary secretion. Ann. Bot. 8: 251-262.

Juniper B. E., Jeffree C. E. 1983. Plant surfaces. Edward Arnold, London.

Kondratowicz P., Czekalski M. 1984. Lecznicze właściwości różaneczników flory Związku Radzieckiego. / Medicinal properties of rhododendrons of flora of the Soviet Union. Wszechświat, 10: 325-327.

Maurizio A., Grafl I., 1969. Das Trachtpflanzenbuch. Ehrenwirth Verlag, München.

Miroslavov E. A., 1974. Struktura i funktsiya epidermisa lista pokrytosemennych rastenij. Nauka, Leningrad.

Muras P. 1994. Rozmnażanie różaneczników z grupy 'Catawbiense - Hybridum' z sadzonek pędowych pobieranych $\mathrm{z}$ młodych roślin podczas przycinania. / Propagation of rhododendrons belonging to the group 'Catawbiense - Hybridum' from shoot seedlings collected from young plants during pruning. Erica Rocz. Rośl. Wrzos. 5: 42-45.

Philipson M. N. 1985. The Rhododendron nectary. Notes RBG Edinb. 43(1): 117-131.

Seneta W., Dolatowski J. 2007. Dendrologia. Wydaw. Nauk. PWN, Warszawa.

Weryszko-Chmielewska E., Chwil M. 2005. Morphological features of the nectary and of the pollen grains and the foraging value of the flowers of yellow azalea (Rhododendron luteum Sweet.). J. Apic. Sci. 49(2): 5-12.

Weryszko-Chmielewska E., Chwil M. 2007. Micromorphology of the epidermis of the floral nectary of Rhododendron japonicum (A. Gray) J.V. Suringar ex E.H. Wilson. Acta Agrobot. 60(1): 45-53. 
Weryszko-Chmielewska E., Sawidis T., Matusiewicz J. 2003. Przystosowania ekologiczne kwiatów różanecznika żółtego (Rhododendron luteum Sweet) z uwzględnieniem struktury nektarnika. / Ecological adaptations of Rhododendron luteum Sweet including the nectary structure. Ann. Univ. Mariae Curie-Skłodowska. Sect. EEE, 13: 17-21.

\section{Mikromorfologia nektarników Rhododendron catawbiense Michx. w różnych fazach rozwoju kwiatu}

\section{Streszczenie}

Analizy budowy nektarników kwiatowych Rhododendron catawbiense Michx. wykonano przy zastosowaniu mikroskopu: stereoskopowego, świetlnego i skaningowego elektronowego. Nektarniki pobierano w różnych fazach rozwoju: zamkniętego pąka, pękającego pąka i w pełni kwitnienia. Gruczoł nektarnikowy wykazuje wyraźne żebrowania odpowiadające pięciu niewielkim żebrom zalążni słupka. W szczytowej części gruczołu wyrastają jedno- i wielokomórkowe włoski mechaniczne występujące $\mathrm{w}$ dużym zagęszczeniu. Górna powierzchnia nektarnika różni się silniejszym stopniem rozwoju kutykuli od powierzchni bocznej. Aparaty szparkowe rozmieszczone są równomiernie na górnej powierzchni i w wyższych strefach bocznej ściany. Na powierzchni komórek szparkowych kutykula tworzy wyraźne prążki. Obserwowano aparaty szparkowe w różnych stadiach rozwoju oraz początek sekrecji nektaru, który odbywa się już w zamkniętym pąku. 